\title{
Gambaran Pola Kuman pada Bilah Laringoskop di Ruang Operasi Rumah Sakit Dr. Hasan Sadikin Bandung
}

\author{
Edwin Haposan, ${ }^{1}$ Suwarman, ${ }^{2}$ Ike Sri Redjeki ${ }^{2}$ \\ ${ }^{1}$ SMF Anestesi dan Terapi Intensif Rumah Sakit Umum Daerah Sekarwangi, \\ ${ }^{2}$ Departemen Anestesiologi dan Terapi Intensif \\ Fakultas Kedokteran Universitas Padjadjaran/Rumah Sakit Dr. Hasan Sadikin Bandung
}

\begin{abstract}
Abstrak
Kebiasaan cara membersihkan bilah laringoskop dapat menyebabkan komplikasi karena potensial kontak dengan mikro-organisme patogen dan dapat menyebabkan infeksi nosokomial. Tujuan penelitian adalah mengetahui gambaran kuman pada bilah laringoskop dengan metode pembersihan yang dilakukan di Rumah Sakit Dr. Hasan Sadikin (RSHS) Bandung. Penelitian dilakukan menggunakan metode deskriptif observasional dengan cara melakukan pemeriksaan kultur kuman pada 19 bilah laringoskop sebelum digunakan dan yang sudah dibersihkan sesudah tindakan laringoskopi, serta 14 sumber air untuk membersihkan bilah laringoskop di ruang operasi RSHS Bandung pada tanggal Desember 2014-Januari 2015. Hasil penelitian ini ditemukan gambaran pola kuman komensal pada bilah laringoskop yang digunakan sebelum tindakan laringoskopi, yaitu Bacillus spp. 10 dari 19. Ditemukan gambaran pola kuman patogen pada bilah laringoskop yang sudah dibersihkan setelah tindakan laringoskopi di ruang operasi, yaitu Candida non albicans 1 dari 19, Acinobacter baumanii dan Staphylococcus haemolyticus 1 dari 19, serta Klebsiella pneumoniae dan Pseudomonas aeruginosa 1 dari 19. Simpulan, ditemukan kuman patogen pada bilah laringoskop yang sudah dibersihkan sesudah tindakan laringoskopi dan air yang digunakan untuk membersihkan bilah laringoskop di Rumah Sakit Dr. Hasan Sadikin Bandung.
\end{abstract}

Kata kunci: Bilah laringoskop, infeksi nosokomial, laringoskopi, pola kuman

\section{Bacterial Mapping of Laryngoscope Blade at the Operating Theater of Dr. Hasan Sadikin General Hospital Bandung}

\begin{abstract}
The habit of cleaning laryngoscope blades can cause complications due to potential contact with patogenic microorganisms that may cause nosocomial infections. The aim this study was to determine the microbial patterns on the laryngoscope blades cleaned using the cleaning methods applied in Dr. Hasan Sadikin General Hospital (RSHS) Bandung. This study was conducted using the descriptive observational method by taking samples of bacterial culture from 19 laryngoscope blades before laryngoscopy procedures and 19 cleaned laryngoscope after laryngoscopy, as well as from the 14 water sources that were used for cleaning laryngoscope blades in the operating theaters of RSHS Bandung in December 2014-January 2015. The results of this study revealed a commensal microbial pattern of Bacillus spp. on 10 of 19 laryngoscope blades before they were used in laryngoscopy precedures. It was revealed that among the laryngoscopes blade that had been cleaned after laryngoscopy in the operating room. 1 of 19 was found to have a nonCandida albicans pattern, 1 of 19 had Acinobacter baumannii and Staphylococcus haemolyticus pattern, and 1 of 19 had Klebsiella pneumoniae and Pseudomonas aeruginosa pattern. Hence, it can be concluded that pathogenic germs are found in laryngoscope bplades that have been cleaded after laryngoscopy and water that is used to clean them in Dr. Hasan Sadikin General Hospital Bandung.
\end{abstract}

Key words: Bacterial mapping, direct laryngoscopy, laryngoscope blades, nosocomial infections

Korespondensi: Edwin Haposan Martua, dr., SpAn. M. Kes, SMF Anestesi dan Terapi Intensif Rumah Sakit Umum Daerah Sekarwangi, Jl. Siliwangi No. 49, Cibadak, Kab. Sukabumi, Tlpn./Faks. 0266-531261, Mobile 08122421975, Email edwin70_dr@yahoo.com 


\section{Pendahuluan}

Tindakan anestesi merupakan salah satu jenis pelayanan dalam kamar operasi. Penggunaan laringoskop dalam anestesi sangat penting sebagai alat untuk membantu visualisasi pita suara pada saat dilakukan pemasangan pipa endotrakeal. ${ }^{1-3}$

Laringoskopi merupakan prosedur invasif yang menyebabkan kontak bilah laringoskop dengan selaput lendir mukosa, saliva, dan juga darah apabila terjadi trauma. Kebiasaan cara penggunaan dan membersihkan laringoskop yang bervariasi menyebabkan efek samping di antaranya kontak dengan mikroorganisme berbahaya. Penggunaan selubung plastik habis pakai pada gagang dan bilah laringoskop dapat melindungi terhadap kontak dengan saliva dan darah serta mengurangi kontaminasi silang. Bilah laringoskop membutuhkan disinfeksi untuk membunuh organisme vegetatif, tetapi tidak diharuskan untuk dilakukan sterilisasi. Hendaknya dilakukan perendaman dan juga penyikatan dengan larutan deterjen sebelum dilakukan disinfeksi. ${ }^{2-4}$

Pembersihan atau pencucian adalah proses menghilangkan bahan-bahan yang menular dan bahan organik secara fisik seperti debu, cairan tubuh seperti darah, sekret, muntahan, dan lain-lain. Hal ini merupakan prasyarat penting untuk disinfeksi dan sterilisasi yang dapat dilakukan secara manual dan mekanik atau menggunakan kombinasi kedua metode. Teknik pembersihan secara manual harus dilakukan hanya bila metode yang ada tidak sesuai atau tidak tersedia. Proses ini dilakukan menggunakan air, sabun deterjen, dan mencuci dengan sikat. Hal tersebut adalah prasyarat utama yang memang harus dilakukan sebelum disinfeksi dan sterilisasi. ${ }^{5}$

Disinfeksi atau disebut juga dekontaminasi alah proses penggunaan bahan yang bersifat fisik atau kimia atau pasteurisasi untuk menonaktifkan sifat patogenitas pada material yang digunakan sehingga mikro-organisme tidak menularkan partikel menular sehingga material tersebut aman untuk dipergunakan kembali ataupun dibuang. Proses tersebut dapat menghilangkan hampir seluruh mikro- organisma kecuali spora. Disinfeksi merupakan pemusnahan mikro-organisme tidak berspora (vegetative) seperti staphylococcus, salmonella, serta berbagai macam virus. Dekontaminasi merupakan suatu kombinasi proses termasuk membersihkan, disinfeksi, dan atau sterilisasi material yang dapat digunakan berulang yang telah terpakai untuk digunakan kembali. ${ }^{5}$

Disinfektan dibagi beberapa tingkat, yaitu high, intermediate, dan low level disinfectant. High level disinfectant adalah golongan yang dapat membunuh seluruh mikro-organisme kecuali spora bakteri. Golongan ini digunakan pada instrumen bedah yang tidak tahan terhadap sterilisasi (bahan plastik), digunakan untuk alat-alat invasif, misalnya endoskopi dan didahului dengan pembersihan permukaan material, contoh: glutaraldehid 2\%, hidrogen peroksida $3 \%$ hingga $25 \%$, dan klorin dioksida 100-1.000 ppm.

Intermediate level disinfectant digunakan pada permukaan instrumen yang berpotensi terkontaminasi oleh mikro-organisme seperti pada bilah laringoskop, flexible fiberoptic endoscope, vaginal specula, dan juga anesthesia breathing circuits. Bahan yang tidak dapat membunuh bakteri spora antara lain alkohol (ethyl, isoprophyl) 70\% hingga 95\%, Iodophor compounds 30-50 ppm/L, phenolic compound 0,4-5\%. Low level desinfektan digunakan pada bahan non-kritikal instrumen: blood pressure cuff, stetoskop, elektroda elektrokardiogram, contoh: quartemary ammonium compounds $(0,4-1,6 \%){ }^{5}$

Pada penelitian tahun 2009 di Baghdad dilakukan isolasi kuman di kamar operasi pada kurun waktu Februari 2001-Desember 2002, didapatkan 116 sampel yang diambil dari 12 kamar operasi dan didapatkan Staphylococcus epidermidis (39,1\%), Pseudomonas aeruginosa $(30,4 \%)$, Staphylococcus aureus $(17,4 \%)$, dan pada tahun 2002, bakteri coliform merupakan bakteri yang terbanyak. $^{6}$

Pada penelitian tahun 2011 di Ahaz, Iran, dilakukan di tujuh rumah sakit pada bulan April 2006 sampai dengan Januari 2007 terhadap 1.208 sampel (1.156 sampel swab kapas basah, 8 sampel air dialisis, dan 44 sampel air bekas cuci tangan) yang diambil dari alat medis 
dan permukaan benda-benda di rumah sakit. Sampel tersebut diambil dari kamar operasi, unit perawatan intensif, bangsal ortopedi/ bedah, unit neonatal, dapur, dan ruang dialisis. Selain itu, dilakukan juga evaluasi terhadap kontaminasi bakteri dari tangan pegawai dan beberapa peralatan medis. Semua sampel dari permukaan benda-benda tersebut diambil setelah dilakukan dekontaminasi. Hasil yang didapatkan, yaitu 57\% sampel positif dengan $>10$ spesies yang terisolasi. Staphylococcus coagulase $(36,1 \%)$ dan Klebsiella pneumoniae $(8,9 \%)$ merupakan bakteri gram positif dan negatif yang dominan. Kuman ini didapatkan dari tangan pegawai $(79,5 \%)$, ruang dapur $(71,4 \%)$, ruang staf $(61,1 \%)$, dan peralatan $(57,8 \%)$ adalah tempat yang paling terinfeksi. Gram negatif enterik basil (50\%) didapatkan dari pegawai pelayanan makanan dan gram positif coccus $(46,6 \%)$ yang merupakan isolat dominan dari spesimen tangan tenaga medis dan $60 \%$ adalah methicillin resistance Staphylococus aureus (MRSA). ${ }^{7}$

Penggunaan laringoskop rutin dilakukan saat induksi anestesi umum. Petugas kesehatan terkadang kurang memperhatikan komplikasi infeksi akibat dari prosedur pembersihan bilah laringoskop yang kurang tepat. Kejadian infeksi iatrogenik yang berkaitan dengan kontaminasi kuman akibat penggunaan bilah laringoskop dilaporkan beberapa literatur ilmiah. Infeksi silang tersebut dapat terjadi antarpasien dan menyebabkan infeksi nosokomial. ${ }^{3}$

Infeksi nosokomial merupakan infeksi pada pasien di rumah sakit yang diakibatkan oleh penyebab selain dari keadaan yang diderita pasien. Infeksi tersebut diperoleh di rumah sakit atau pada fasilitas pelayanan kesehatan lain, dan infeksi tersebut tidak dialami pasien pada saat awal masuk rumah sakit. ${ }^{8}$

Pada saat ini, disinfeksi bilah laringoskop di kamar operasi Rumah Sakit Dr. Hasan Sadikin Bandung dilakukan dengan cara manual, yaitu dibersihkan dengan chlorhexidine gluconate kemudian dibilas dengan air mengalir. Tujuan penelitian ini adalah memberikan gambaran pola kuman pada bilah laringoskop dan air di ruang operasi Rumah Sakit Dr. Hasan Sadikin Bandung. Hal tersebut dapat dijadikan masukan dalam hal pengendalian infeksi di Rumah Sakit Dr. Hasan Sadikin Bandung.

\section{Subjek dan Metode}

Penelitian ini bersifat deskriptif observasional. Subjek penelitian adalah bilah laringoskopyang dipergunakan dan air untuk membersihkan bilah laringoskop di ruang operasi lantai 3 dan 4 Rumah Sakit Dr. Hasan Sadikin Bandung. Penelitian dilakukan pada periode Desember 2014-Januari 2015.

Sampel penelitian adalah bilah laringoskop yang akan dipergunakan dan dianggap sudah bersih, yang telah digunakan dan dicuci, serta air yang dipergunakan untuk membersihkan bilah laringoskop, yaitu sebanyak 19 buah bilah laringoskop dan 14 tempat/wadah untuk membersihkan bilah laringoskop.

Setelah mengajukan proposal penelitian dan mendapat persetujuan dari Komite Etik Penelitian Kesehatan Fakultas Kedokteran Universitas Padjadjaran/RumahSakitDr.Hasan Sadikin Bandung, peneliti mengumpulkan data pemakaian bilah laringoskop di Instalasi Bedah Sentral lantai 3 dan 4 Rumah Sakit Dr. Hasan Sadikin Bandung. Sampel diambil dari bilah laringoskop yang akan digunakan dan bilah yang sudah dibersihkan setelah tindakan laringoskopi pada hari yang sama, serta air yang dipergunakan untuk membersihkan bilah laringoskop. Sebelum proses pengambilan sampel, dicatat terlebih dahulu ruang operasi, ukuran bilah, tanggal penggunaan, dan tempat mencuci bilah laringoskop.

Pengambilan sampel pertama dilakukan dengan pengapusan bilah laringoskop yang belum dan akan digunakan untuk laringoskopi menggunakan kapas lidi steril dimulai dari pangkal menyusuri lekukan hingga ke ujung, kemudian kembali lagi ke bagian pangkal bilah laringoskop (Gambar 1). Apusan dimasukkan ke dalam media transpor lalu di kirim ke Laboratorium Mikrobiologi Rumah Sakit Dr. Hasan Sadikin Bandung.

Bilah laringoskop yang telah digunakan untuk laringoskopi dicuci dengan chlorhexidine gluconate, dibilas dengan air yang mengalir, selanjutnya dikeringkan dengan kain kassa dan 


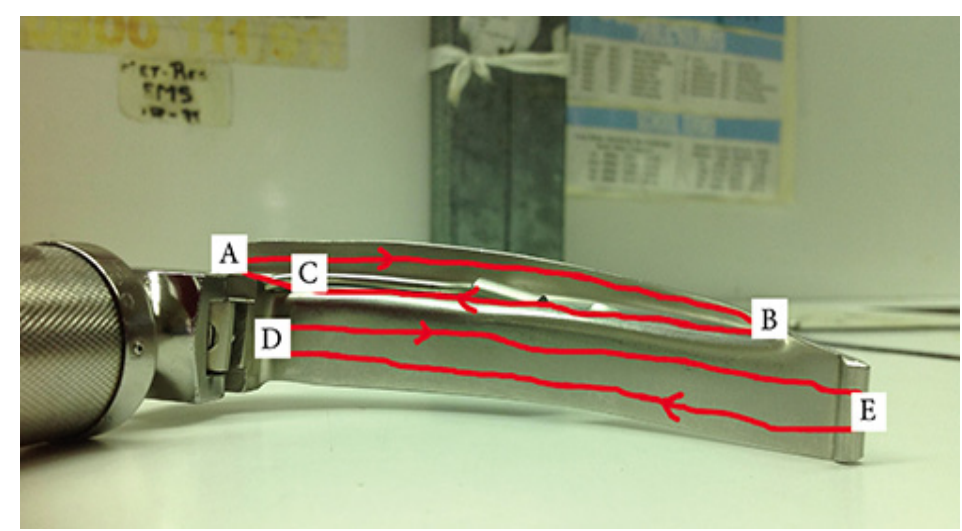

Gambar 1 Metode Apus pada Bilah Laringoskop

Dikutip dari: Lowman dkk. ${ }^{3}$

setelah dianggap bersih kemudian dilakukan pengambilan sampel ke-2 dengan melakukan pengapusan pada bilah laringoskop seperti pengapusan pertama, kemudian dimasukkan ke dalam media transpor. Air yang digunakan untuk mencuci bilah laringoskop sebelumnya ditampung dalam tempat/wadah yang steril juga dikirim ke Laboratorium Mikrobiologi Rumah Sakit Dr. Hasan Sadikin Bandung.

Dilakukan kultur dan hitung jenis kuman di Laboratorium Mikrobiologi Rumah Sakit Dr. Hasan Sadikin Bandung. Semua kuman yang teridentifikasi pada kultur dicatat dan dilaporkan berdasarkan sampel pemeriksaan. Bilah laringoskop dan air yang digunakan untuk membersihkan dapat dianggap positif

\section{Tabel 1 Karakteristik Jenis Kuman pada Apus Bilah Laringoskop Sebelum Tindakan Laringoskopi}

\begin{tabular}{lc}
\hline Jenis Kuman & Jumlah \\
\hline Bacillus spp. & 10 \\
Burkholderia cepacia + & 1 \\
Staphylococcus epidermidis & 1 \\
Staphylococcus aureus & 3 \\
Staphylococcus epidermidis & 2 \\
Staphylococcus haemolyticus & 1 \\
Streptococcus viridans & 1 \\
Klebsiella pneumoniae & 0 \\
Steril & 19 \\
Jumlah &
\end{tabular}

terkontaminasi bila setidaknya terdapat satu koloni dari suatu organisme. Data dianalisis dalam ukuran jumlah dan persentase untuk data kategorik.

\section{Hasil}

Telah dilakukan penelitian gambaran pola kuman terhadap 19 bilah laringoskop serta air di 14 wadah untuk membersihkan bilah laringoskop di ruang operasi Rumah Sakit Dr. Hasan Sadikin Bandung pada tanggal 19 Desember 2014.

\section{Tabel 2 Karakteristik Jenis Kuman pada Apus Bilah Laringoskop yang Dibersihkan Sesudah Tindakan Laringoskopi}

\begin{tabular}{lc}
\hline Jenis Kuman & Jumlah \\
\hline Acinetobacter baumannii + & 1 \\
Staphylococcus haemolyticus & 5 \\
Bacillus spp. & 1 \\
Candida non albicans & 2 \\
Klebsiella pneumoniae & 1 \\
Klebsiella pneumoniae + & 2 \\
Pseudomonas aeruginosa & 2 \\
Staphylococcus epidermidis & 3 \\
Staphylococcus haemolyticus & 2 \\
Streptococcus viridans & 19 \\
Steril & \\
Jumlah & \\
\hline
\end{tabular}




\section{Tabel 3 Karakteristik Jenis Kuman pada Air yang Digunakan untuk Membersihkan Laringoskop di Ruang Operasi}

\begin{tabular}{lc}
\hline Jenis Kuman & Jumlah \\
\hline Bacillus spp. & 7 \\
Enterobacter cloacae & 2 \\
Staphylococcus epidermidis & 1 \\
Pseudomonas aeruginosa & 1 \\
Steril & 3 \\
Jumlah & 14 \\
\hline
\end{tabular}

Gambaran kultur kuman pada apus 19 bilah laringoskop sebelum tindakan laringoskopi ditemukan kuman komensal yang terbanyak, yaitu Bacillus spp. (10 dari 19; Tabel 1).

Gambaran kultur kuman pada apus 19 bilah laringoskop yang dibersihkan sesudah tindakan laringoskopi juga ditemukan kuman komensal yang terbanyak, yaitu Bacillus spp. 5 dari 19. Ditemukan juga kuman patogen, yaitu candida non albicans 1 dari 19 dan acinobacter baumanii serta Staphylococcus haemolyticus (1 dari 19; Tabel 2).

Gambaran hasil kultur kuman dalam air di14 tempat yang digunakan untuk membersihkan bilah laringoskop di ruang operasi ditemukan kuman komensal terbanyak adalah Bacillus spp. (7 dari 14). Ditemukan kuman patogen pseudomonas aeruginosa (1 dari 14; Tabel 3).

\section{Pembahasan}

Laringoskopi merupakan komponen penting pada praktik anestesi yang dilakukan untuk memfasilitasi penempatan endotracheal tube. Laringoskopi adalah prosedur invasif yang mengakibatkan kontak dengan selaput lendir, air liur, serta darah. Berbagai macam mikroorganisme, termasuk mikrob yang berpotensi menimbulkan bahaya dapat berkembang di permukaan bilah laringoskop. Laringoskopi merupakan salah satu sumber penularan infeksi potensial di rumah sakit. Diperlukan proses sterilisasi/disinfeksi bilah laringoskop yang ditemukan mikro-organisme., ${ }^{2,3}$

Beberapa jenis bakteri dapat menyebabkan infeksi nosokomial yang dibagi ke dalam kelompok bakteri komensal yang merupakan flora normal pada manusia yang sehat dan bakteri patogen dengan tingkat virulensi tinggi yang dapat menyebabkan infeksi tanpa bergantung kondisi tubuh. Bakteri komensal menyebabkan infeksi jika pasien mengalami penurunan pada sistem kekebalan tubuh. ${ }^{9}$

Bakteri menyebabkan infeksi nosokomial melalui beberapa cara. Cara pertama adalah infeksi endogen oleh bakteri normal tubuh yang dapat menyebabkan infeksi dikarenakan berpindah tempat dari lingkungan alaminya, kerusakan jaringan, dan juga terapi antibiotik yang tidak rasional. Salah satu contoh adalah bakteri gram negatif pada saluran pencernaan yang dapat menyebabkan infeksi luka operasi setelah pembedahan abdomen atau infeksi saluran kemih pada pasien yang terpasang kateter urin. ${ }^{9}$

Mekanisme lainnya, infeksi silang eksogen yang disebabkan oleh mikro-organisme dari pasien lain atau petugas kesehatan. Bakteri ditransmisikan antarpasien dengan kontak langsung melalui tangan, air liur, droplet, atau cairan tubuh lainnya. Selain itu, dapat pula melalui udara akibat droplet atau debu yang terkontaminasi oleh bakteri yang berasal dari pasien. Mekanisme lain, yaitu melalui petugas kesehatan yang terkontaminasi saat merawat pasien lain (tangan, pakaian, hidung, dan juga tenggorokan) serta merupakan carrier yang tetap atau sementara. Selain itu, dapat pula alat kesehatan yang terkontaminasi bakteri dari pasien, dari tangan petugas kesehatan, pengunjung rumah sakit, dan sumber lain dari lingkungan sekitar (air, makanan, dan cairan lainnya). ${ }^{9}$

Flora utama hidung ialah Corinea bacteria, Staphylococcus (S. epidermidis, S. aureus), streptococcus, diplococcus gram negatif (neisseria, Moraxella catarrhalis), difteroid, kadang lactobacillus. Pada gigi-geligi terdapat flora normal spirochaeta anaerob, spesies prevotella (terutama P. melaninogenica, species fusobakterium, rothia. Jaringan tonsil dan ginggiva, spesies actinomyces, protozoa, ragi (species candida) pada mulut. Pada faring dan trakea terdapat flora normal yang sama. Pada 
bronkus normal terdapat sedikit bakteri. Pada bronkus terminal dan alveoli secara normal steril. Organisme utama pada saluran napas atas terutama faring adalah Streptococcus nonhemoliticus, alfa hemoliticus, S. epidermidis dan Neisseria sp. nonpatogen, staphylococcus, difteroid, haemophyllus, pneumococcus, mycoplasma. ${ }^{10}$

Mikro-organisme patogen dalam sistem pernapasan atas adalah bakteri, jamur, virus seperti Streptococcus pyogenes, Staphylococcus pneumoniae, Rhinovirus, Coronavirus,Candida albicans, Poliovirus, Crynobacterium diptheriae, Fussobacterium sp., Spirochetes, Staphylococcus aureus, Aspergillus, Haemophyllus influenzae, Mycobacterium tuberculosa, Adenovirus, Herpes simplex virus, Nesseria gonorrheae, Parainfluenza virus, Influenza virus, Respiratory syncytial virus, Coxaxie a dan $b$ virus, Epsteinbarr virus. ${ }^{10}$

Dari penelitian ini ditemukan gambaran kuman komensal pada bilah laringoskop yang digunakan sebelum laringoskopi yaitu bacillus spp. sebanyak 10 dari 19 sampel. Ditemukan kuman patogen pada apusan bilah laringoskop yang sudah dibersihkan setelah tindakan laringoskopi, yaitu Candida non albicans yaitu 1 dari 19 sampel, Acinobacter baumanii dan Staphylococcus haemolyticus 1 dari 19 sampel, dan Klebsiella pneumoniae dan juga Pseudomonas aeruginosa 1 dari 14 sampel.

Bakteri komensal dapat mengakibatkan infeksi apabila tubuh mengalami penurunan sistem kekebalan tubuh, sebagai contoh adalah Staphylococcus yang dapat mengakibatkan infeksi pada jalur intravaskular (Escherichia coli) yang dapat menyebabkan infeksi saluran kemih. ${ }^{3,4}$

Staphylococcus aureus merupakan bakteri komensal yang dapat menyebabkan infeksi apabila pasien mengalami penurunan sistem kekebalan tubuh. Contohnya Staphylococcus yang dapat menyebabkan infeksi pada jalur intravaskular (Escherichia coli) yang dapat mengakibatkan infeksi pada saluran kemih. Staphylococcus epidermidis ialah bakteri gram positif merupakan flora normal dalam saluran pernapasan manusia. MeskipunStaphylococcus epidermidis biasanya bukan bakteri patogen, pasien dengan gangguan sistem kekebalan tubuh mempunyai risiko yang lebih tinggi untuk mengalami infeksi. Staphylococcus haemolyticus adalah bakteri gram positif yang berupa flora normal pada kulit. Streptococcus viridans menjadi flora tetap yang utama sepanjang hidup. Pada jumlah normal dan sistem kekebalan tubuh yang baik bakteribakteri ini tidak akan menimbulkan infeksi, tetapi dengan penurunan sistem kekebalan tubuh dan kemampuan jenis Staphylococcus dalam membentuk lapisan biofilm, infeksi Staphylococcus sulit diatasi dengan pemberian antibiotik..$^{1,2}$

Bacillus spp. merupakan flora normal pada mulut bagian atas dan bakteri dominan yang terdapat pada lantai, dinding dan udara yang terdapat di ruang operasi. Bakteri ini dapat hidup bertahun-tahun di dalam lingkungan dan juga sebagian besar tidak menimbulkan penyakit pada manusia. ${ }^{10}$

Burkholderia cepacia adalah bakteri gram negatif yang dapat ditemukan di air, tanah, udara, dan lingkungan yang lembap. Beberapa jamur dan parasit oportunistik seperti Candida albicans dapat menyebabkan infeksi pada pasien yang mengalami penurunan sistem kekebalan tubuh dan mendapatkan terapi antibiotik yang lama. ${ }^{10,12}$

Acinetobacter baumannii ialah jenis bakteri yang unik karena kemampuan untuk bertahan hidup. Acinetobacter baumannii ialah bakteri gram negatif yang dapat menyebabkan infeksi nosokomial pada tubuh manusia. Bakteribakteri seperti Acinetobacter, Pseudomonas, Mycobacterium ini dapat tumbuh pada suhu $44^{\circ} \mathrm{C}$, biasanya didapatkan di tanah, air, daerah yang lembap, dan sediaan steril atau desinfektan. Bakteri ini dapat menjadi salah satu penyebab infeksi nosokomial karena dapat melakukan kolonisasi di unit operasi, medis, persalinan, dan perawatan luka bakar dalam suatu rumah sakit serta berperan dalam infeksi penyakit akut seperti meningitis, pneumonia, dan bakteremia. Hal tersebut disebabkan oleh kemampuan hidup di fasilitas dan peralatan rumah sakit berminggu-minggu dan juga sifat resistensi terhadap antimikrob. Acinetobacter baumannii juga diketahui tahan 
(resisten) terhadap sabun dan juga antiseptik konvensional sehingga kontaminasi koloni bakteri ini pada tangan petugas kesehatan mudah terjadi. ${ }^{11}$

Kuman patogen yang ditemukan seperti Pseudomonasaeruginosa, Klebsiela pneumoniae dan Staphylococcus aureus merupakan kuman penyebab hospital acquired pneumonia atau HAP, ventilator associated pneumonia (VAP), dan health care associated pneumonia atau juga disebut HCAP. Angka kejadian sebenarnya dari kasus pneumonia nosokomial di Indonesia tidak diketahui antara lain dikarenakan data nasional tidak ada dan data yang ada hanya berasal dari beberapa rumah sakit swasta dan pemerintah serta angkanya sangat bervariasi. Pneumonia nosokomial dapat disebabkan oleh kuman yang bukan multi drug resistance (MDR), misalnya Staphylococcus pneumoniae, Haemophylus influenzae, Methicillin resistance Staphylococcus aureus (MRSA). Kuman MDR, yaitu Pseudomonas aeruginosa, Escherichia coli, Klebsiella pneumoniae, Acinetobacter spp. dan gram positif seperti Methicillin resistance Staphylococcus aureus (MRSA). Pneumonia nosokomial yang disebabkan oleh jamur, kuman anaerob, dan virus jarang terjadi. ${ }^{4,8}$

Bakteri pseudomonas sp. dapat diisolasi pada air, daerah yang lembap, serta berkoloni di saluran pencernaan pasien yang dirawat di rumah sakit. Ada kemungkinan terjadi infeksi silangPseudomonasaeruginosa. Meskipuntidak terjadi kontak langsung gagang laringoskop dengan pasien, kemungkinan potensial terjadi kontaminasi pada bilah laringoskop karena pada bilah yang bersentuhan dengan gagang dan tangan petugas medis saat dalam keadaan posisi terlipat menutup. Oleh karena itu, hal ini dapat menjadi sumber potensial infeksi silang., ${ }^{9,12}$

Klebsiella pneumoniae merupakan salah satu bakteri gram negatif, nonmotil, fakultatif anaerob, melakukan fermentasi laktosa dan tidak tertutup oleh selubung, serta memiliki simpai polisakarida berukuran besar sehingga memberi hasil positif pada tes dekarboksilase lisin dan sitrat. Bakteri ini merupakan bakteri yang normal ditemukan di rongga mulut, kulit, dan usus. Bakteri ini dapat menjadi patogen jika terinspirasi dengan ditemukannya bakteri pada sputum. Penyakit yang ditimbulkan oleh bakteri ini antara lain bronkopneumonia dan pneumonia bakteri gram negatif. Hampir semua pneumonia disebabkan oleh bakteri ini. Klebsiella pneumoniae terdapat dalam saluran napas dan feses sekitar 5\% orang normal dan dapat menyebabkan pneumonia bakterial. Infeksi bakteri ini dapat terjadi terutama pada pasien dengan gangguan imunologi, geriatrik, diabetes, keganasan, dan juga gangguan pada ginjal. ${ }^{3,12}$

Prosedur disinfeksi bilah laringoskop di kamar operasi RSHS Bandung yang dilakukan dengan cara manual, yaitu dibersihkan dengan chlorhexidine gluconate dan dibilas dengan air mengalir, ditemukan kuman komensal pada bilah laringoskop sebelum dan sesudah digunakan tindakan laringoskopi serta kuman patogen pada bilah laringoskop yang sudah digunakan dan air untuk membersihkan bilah laringoskop.

Menurut Centers for Disease Control and Prevention (CDC) bilah laringoskop termasuk ke dalam alat yang sangat berpotensi untuk terkontaminasi sehingga perlu sekali dilakukan proses disinfeksi dan juga sterilisasi. Terdapat beberapa cara untuk melakukan disinfeksi dan sterilisasi pada bilah laringoskop, di antaranya adalah teknikdekontaminasidenganair hangat, ethyl atau isopropyl alcohol (70-90\%), sodium hypoclorite, detergen phenolic germicidal atau iodophor germicidal, glutaraldehyde, dan autoclaving. Autoclaving atau perendaman dalam larutan glutaraldehyde merupakan cara disinfeksi yang dianjurkan. Bilah laringoskop dicuci dan disinfeksi dengan direndam dalam desinfektan glutaraldehyde selama 5-10 menit, tetapi pemakaian dan perendaman alat dalam jangka waktu lama dapat merusak hubungan antara bola lampu dan bilah laringoskop. ${ }^{4,13}$

\section{Simpulan}

Berdasarkan hasil penelitian dan pembahasan dapat diambil simpulan bahwa terdapat kuman komensal pada bilah laringoskop yang akan digunakan untuk tindakan laringoskopi, yaitu bakteri bacillus spp. Didapatkan gambaran 
kuman patogen pada bilah laringoskop yang telah dibersihkan sesudah dilakukan tindakan laringoskopi, yaitu Candida nonalbicans, Acinobacter baumanii dan Staphylocuccus haemolyticus, serta Klebsiella pneumoniae dan Pseudomonas aeruginosa. Ditemukan juga kuman patogen pada air yang digunakan untuk membersihkan bilah laringoskop, yaitu Pseudomonas aeruginosa. Mengacu pada hasil penelitian ini, perlu dilakukan evaluasi dan dibuatkan standar perlakuan penggunaan dan pembersihan bilah laringoskop serta air di ruang operasi pada khususnya dan seluruh bagian Rumah Sakit Dr. Hasan Sadikin Bandung pada umumnya untuk menghindari kontaminasi yang dapat mengakibatkan infeksi nosokomial.

\section{Daftar Pustaka}

1. KlockP, Ovassapian A. Airway management. Dalam: Longnecker D, penyunting. Anesthesiology. Edisi ke-3. New York: McGraw-Hill; 2008. hlm. 685-717.

2. Butterworth J, Mackey D, Wasnick J, penyunting. Airway management. Morgan \& Mikhail's clinical anesthesiology. Edisi ke-5. New York: McGraw-Hill; 2013.

3. Lowman W, Venter L, Scribante J. Bacterial contamination of re-usable laryngoscope blades during the course of daily anaesthetic practice. S Afr Med J. 2013;103(6):386-9.

4. Machan M. Infection control practices of laryngoscope blades: a review of the literature. AANA J. 2012;80(4):274-8.

5. Lewis T. Infection prevention and control team. Policy on cleaning and disinfection of equipment, surfaces, environment and skin. Edisi ke-5. NorthBeccles: ECCH; 2013.

6. Ensayef S, Shalchi S, Sabbar M. Microbial contamination in the operating theatre: a study in a hospital in Baghdad. Eastern Mediterran Health J. 2009;15(1):219-23.

7. Ekrami A, Kayedani A, Jahangir M, Kalantar E, Jalali M. Isolation of common aerobic bacterial pathogens from the environment of seven hospital. JJM. 2011;4(2):75-82.

8. Lewis T. Infection prevention and control team. Policy on cleaning and disinfection of equipment, surfaces, environment and skin. Edisi ke-5. NorthBeccles: ECCH; 2013.

9. Smith A. Equipment decontamination policy. Dalam: Royal Cornwall Hospital, penyunting. St Clare Street: NHS; 2012. hlm. 1-11.

10. Brooks G, Carroll K, Butel J, Morse S, Mietzner $\mathrm{T}$, penyunting. Normal human microbiology. Jawetz, Melnick, Adelberg's medical microbiology. Edisi ke-26. New York: Mc Graw-Hill; 2013. hlm. 165-74.

11. Alsan M, Klompas M. Acinobacter baumannii: an emerging and important pathogen. J Clin Outcomes Manag. 2010;17(8):363-9.

12. Detrick B, penyunting. Immunology. Jawetz, Melnick, Adelberg's medical microbiology. Edisi ke-26. New York: Mc Graw Hill; 2013. hlm. 123-48.

13. Rutala W, Weber D. Disinfection of healthcare equipment. Guideline for disinfection and sterilization in healthcare facilities. Central for Disease Control. North Carolina: U.S. Department of Health and Human Services; 2008. 